\title{
Computer Simulation of a Biomass Gasification-solid Oxide Fuel Cell Power System using Aspen Plus
}

\author{
Wayne Doherty \\ Technological University Dublin, wayne.doherty@tudublin.ie \\ Anthony Reynolds \\ Technological University Dublin, anthony.reynolds@tudublin.ie \\ David Kennedy \\ Technological University Dublin, david.kennedy@tudublin.ie
}

Follow this and additional works at: https://arrow.tudublin.ie/engschmecart

Part of the Energy Systems Commons, and the Thermodynamics Commons

\section{Recommended Citation}

Doherty, W., Reynolds, A., Kennedy, D.: Computer Simulation of a Biomass Gasification-Solid Oxide Fuel Cell Power System Using Aspen Plus. Energy, 2010, Vol.35, pp.4545-4555. doi:10.1016/

j.energy.2010.04.051

This Article is brought to you for free and open access by the School of Mechanical and Design Engineering at ARROW@TU Dublin. It has been accepted for inclusion in Articles by an authorized administrator of ARROW@TU Dublin. For more information, please contact arrow.admin@tudublin.ie, aisling.coyne@tudublin.ie, gerard.connolly@tudublin.ie.

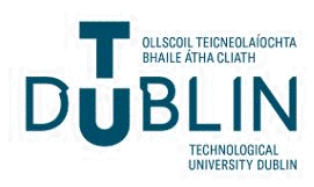




\title{
Computer simulation of a biomass gasification-solid oxide fuel cell power system using
}

\section{Aspen Plus}

\author{
Wayne Doherty ${ }^{*}$, Anthony Reynolds, David Kennedy
}

Department of Mechanical Engineering, Dublin Institute of Technology, Bolton Street, Dublin 1, Ireland

Received

\begin{abstract}
The operation and performance of a solid oxide fuel cell (SOFC) stack on biomass syn-gas from a biomass gasification combined heat and power (CHP) plant is investigated. The objective of this work is to develop a model of a biomass-SOFC system capable of predicting performance under diverse operating conditions. The tubular SOFC technology is selected. The SOFC stack model, equilibrium type based on Gibbs free energy minimisation, is developed using Aspen Plus. The model performs heat and mass balances and considers ohmic, activation and concentration losses for the voltage calculation. The model is validated against data available in the literature for operation on natural gas. Operating parameters are varied; parameters such as fuel utilisation factor $\left(U_{f}\right)$, current density $(j)$ and steam to carbon ratio $(S T C R)$ have significant influence. The results indicate that there must be a trade-off between voltage, efficiency and power with respect to $j$ and the stack should be operated at low STCR and high $U_{f}$. Operation on biomass syn-gas is compared to natural gas operation and as expected performance degrades. The realistic design operating conditions with regard to performance are identified. High efficiencies are predicted making these systems very attractive.
\end{abstract}

Keywords: Tubular solid oxide fuel cell, Biomass gasification, Syn-gas, Aspen Plus, Modelling, Model validation

\footnotetext{
* Corresponding author. Tel.: +353 1 4022976; fax: +35314023991.

E-mail address: wayne.doherty@dit.ie (W. Doherty).
} 


\section{Nomenclature}

\section{Roman letters}

$A=$ constant used in Eqs. (9) and (10)

$B=$ constant used in Eq. (10)

$D=$ diffusion coefficient, $\mathrm{m}^{2} / \mathrm{s}$

$D_{A n(e f f)}=$ anode effective diffusion coefficient, $\mathrm{m}^{2} / \mathrm{s}$

$D_{\text {Cat (eff })}=$ cathode effective diffusion coefficient, $\mathrm{m}^{2} / \mathrm{s}$

$D_{m}=$ cell mean diameter, $\mathrm{m}$

$E=$ activation energy, $\mathrm{J} / \mathrm{mol}$

$F=$ Faraday constant, $\mathrm{C} / \mathrm{mol}$

$I=$ current, A

$L H V_{\text {biomass }}=$ lower heating value of biomass, $\mathrm{kJ} / \mathrm{kg}$

$L H V_{\text {fuel }}=$ lower heating value of fuel, $\mathrm{kJ} / \mathrm{kmol}$

$M=$ molecular weight, $\mathrm{kg} / \mathrm{kmol}$

$P=$ pressure, atm

$P_{\text {comp }}=$ electrical power requirement of compressors, $\mathrm{kW}$

$P_{e l, A C}=$ electrical AC power, $\mathrm{kW}$

$P_{e l, D C}=$ electrical DC power, $\mathrm{kW}$

$P_{i}=$ partial pressure of gaseous component $i$, bar

$P_{\text {SOFC }}=$ SOFC operating pressure, $\mathrm{Pa}$

$P_{\text {syngas }}=$ input fuel pressure, $\mathrm{Pa}$

$P^{O}=$ reference pressure, bar

$\dot{Q}=$ useful heat, $\mathrm{kW}$

$R_{\text {Act }}=$ specific resistance, $\Omega \mathrm{m}^{2}$

$R_{g}=$ molar gas constant, $\mathrm{J} / \mathrm{mol} \mathrm{K}$

$S=$ active area, $\mathrm{m}^{2}$

$T_{\text {avg }}=$ average temperature, $\mathrm{K}$

$T_{o p}=$ SOFC operating temperature, $\mathrm{K}$ 
$U_{a}=$ air utilisation factor

$U_{f}=$ fuel utilisation factor

$V=$ voltage, $\mathrm{V}$

$j=$ current density, $\mathrm{A} / \mathrm{m}^{2}$

$k=$ pre-exponential factor Eqs. (13) and (14), $\mathrm{A} / \mathrm{m}^{2}$

$m=$ slope Eqs. (13) and (14)

$\dot{m}_{\text {biomass }}=$ biomass mass flow rate, $\mathrm{kg} / \mathrm{s}$

$n=$ molar flow rate, $\mathrm{kmol} / \mathrm{s}$

$r=$ electrode pore radius, $\mathrm{m}$

$t=$ cell component thickness, $\mathrm{m}$

$v=$ Fuller diffusion volume

$w=$ cell component width, $\mathrm{m}$

$y_{i}=$ molar fraction of gaseous component $i$

$y_{i}{ }_{i}=$ molar fraction of gaseous component $i$ in bulk flow

\section{Greek letters}

$\Delta \bar{g}_{f}=$ molar Gibbs free energy of formation, $\mathrm{J} / \mathrm{mol}$

$\delta_{O 2}=$ constant in Eq. (16)

$\varepsilon=$ electrode porosity

$\eta_{C H P, \text { gross }}=$ plant gross CHP efficiency

$\eta_{e l, g r o s s}=$ gross AC efficiency

$\eta_{e l, n e t}=$ net AC efficiency

$\xi=$ electrode tortuosity

$\rho=$ resistivity, $\Omega \mathrm{m}$

Subscripts

$A=$ anode

$A c t=$ activation 
$C=$ cathode

Conc $=$ concentration

$E=$ electrolyte

Int $=$ interconnection

$K=$ Knudsen

$N=$ Nernst

Ohm $=$ ohmic

$($ eff $)=$ effective

$i=$ gaseous component

$k=$ second gaseous component in a binary mixture

\section{Introduction}

In the context of both climate change mitigation and energy security biomass is among the most promising renewable energy sources. Traditionally, energy is recovered from biomass through combustion at low electrical efficiency (20-25\%). Biomass gasification coupled with advanced power generation technologies such as fuel cells offer much higher efficiencies. Reported electrical efficiencies for biomass gasification-solid oxide fuel cell (SOFC) systems range from $23-50 \%$ [1]. These systems offer highly efficient renewable energy and are modular in nature making them ideal for decentralised combined heat and power (CHP) applications and as a result have recently gained much attention [2-9].

Gasification occurs when a controlled amount of oxidant (pure oxygen $\left(\mathrm{O}_{2}\right)$, air, steam) is reacted at high temperatures with available carbon in biomass or other carbonaceous material within a gasifier, producing a combustible gas (syn-gas). Syn-gas typically contains hydrogen $\left(\mathrm{H}_{2}\right)$, carbon monoxide $(\mathrm{CO})$, methane $\left(\mathrm{CH}_{4}\right)$, carbon dioxide $\left(\mathrm{CO}_{2}\right)$, water $\left(\mathrm{H}_{2} \mathrm{O}\right)$, nitrogen $\left(\mathrm{N}_{2}\right)$ and other components such as higher hydrocarbons. Air gasification produces a poor quality gas with regard to heating value, around $4-7 \mathrm{MJ} / \mathrm{m}^{3}$ higher heating value (HHV), while $\mathrm{O}_{2}$ and steam blown processes result in a syn-gas with a heating value in the range of $10-18 \mathrm{MJ} / \mathrm{m}^{3}$ (HHV) [10-12]. A biomass syn-gas composition typical of the dual fluidised bed (DFB) steam gasification technology currently in operation at the Güssing demonstration biomass gasification CHP plant in Austria was used in this study. 
The SOFC is a highly efficient energy conversion device due to the fact that it converts the chemical energy contained in a fuel gas directly to electrical energy by means of electrochemical reactions. SOFCs can utilise a wide spectrum of fuels (natural gas, coal and biomass syn-gas, liquid fuels including methanol and kerosene [13]) due to their high operating temperatures. The tubular SOFC technology, developed by Siemens Power Generation Inc (SPGI) is considered to be the most advanced and is approaching commercialisation; therefore it was selected for this study. Various models have been developed previously to simulate tubular SOFC performance, many of them for operation on humidified $\mathrm{H}_{2}$ or natural gas [14-20]. A review of SOFC models can be found in the literature [21].

There is a need for SOFC models with short computational times that are easily calibrated to match the continuous and rapid technological advances in the field. In the present study the operation and performance of a tubular SOFC stack (SPGI design) on biomass syn-gas was investigated. The objective of this work was to develop a model of a biomass-SOFC system capable of predicting performance under diverse operating conditions.

Aspen Plus was used to model the SOFC stack. There is no built in model that can represent a SOFC. A common approach is to develop a complete SOFC stack model in a programming language and link it to Aspen Plus as a subroutine [22]. The subroutine must incorporate complex phenomena such as chemical/electrochemical reactions and heat and mass transfer, making them difficult and time consuming to develop and use. This type of model would not achieve the objectives of this work. An alternative method proposed by Zhang et al. [22], using existing Aspen Plus unit operation blocks with minimum requirements for linking of a subroutine was used. The equilibrium model, which is based on Gibbs free energy minimisation, performs heat and mass balances and considers the ohmic, activation and concentration losses for the voltage calculation. Equations reported by Song et al. [23] were used to calculate ohmic loss. Achenbach's semi-empirical correlations were implemented to determine the activation loss [24]. The equations derived by Chan et al. [25] were used for the calculation of the concentration loss.

\section{System description and software}

\subsection{SOFC stack}


The $100 \mathrm{~kW}$ CHP tubular SOFC stack developed by SPGI was selected and modelled. This unit was chosen as it has been operated for over 36000 hours on natural gas [26] and there is a wealth of published data available that may be used for model validation. The operation of the stack is as follows:

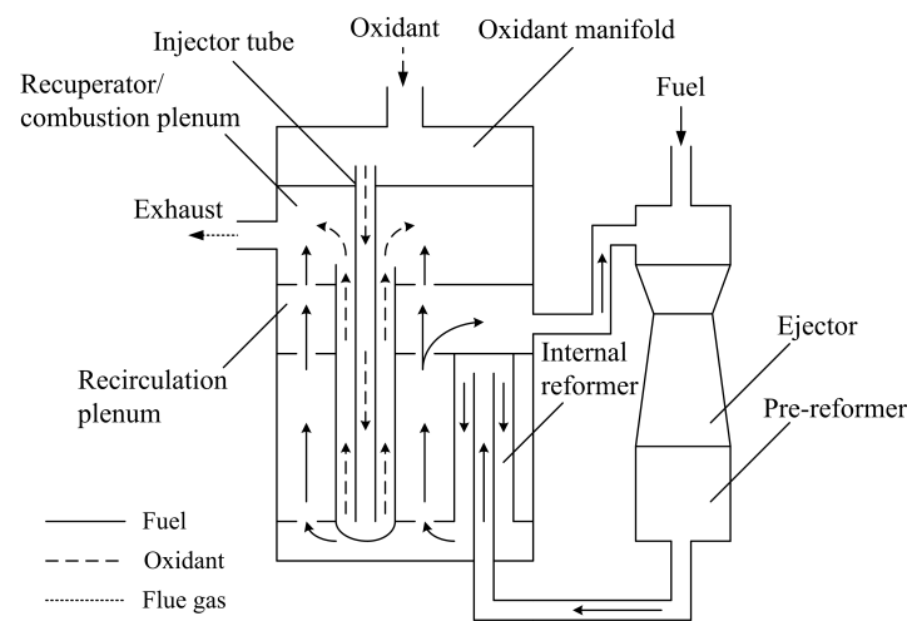

Fig. 1. SOFC stack flow diagram.

With reference to Fig. 1, the oxidant stream is fed via injector tubes, placed centrally in each SOFC, to the closed end of the cells. The oxidant then flows back through the annular space formed by the cathode surface and the injector tube to the open end. The oxidant is electrochemically reacted with the fuel supplied to the anode as it flows over the cathode surface. Cleaned fuel gas is supplied to the ejector where it is mixed with depleted fuel from the recirculation plenum. This anode recycle loop provides the steam and heat required for the steam reforming process. The mixed fuel then passes through the pre-reformers which convert the higher hydrocarbons and a small portion of the $\mathrm{CH}_{4}$ adiabatically to $\mathrm{H}_{2}$ and $\mathrm{CO}$. The partially reformed fuel enters the internal reformers and using the heat generated by the exothermic electrochemical reactions occurring in the SOFC stack it is reformed further. The fuel then flows along the anode surface from the closed end to the open end, parallel to the direction of the oxidant flow and is electrochemically oxidised, generating electricity and increasing the temperature of both streams. A portion of the depleted fuel is recycled, the quantity of which depends on the required steam to carbon ratio $(S T C R)$ and the remainder is reacted with the depleted oxidant in the combustion plenum. The generated heat serves to preheat the incoming oxidant stream in the injector tubes. The high temperature exhaust gas may then be utilised in a district heating system. 


\subsection{Güssing CHP plant}

The Güssing CHP plant has been in operation since 2001 and utilises $8 \mathrm{MW}$ of wood chip fuel to produce 2 $\mathrm{MW}_{\mathrm{e}}$ of electricity by means of a gas engine (GE Jenbacher J620) and 4.5 $\mathrm{MW}_{\text {th }}$ of heat. The configuration of the plant is shown in Fig. 2. The biomass syn-gas is produced using a DFB steam gasifier. This type of gasifier operates with two separate zones, the combustion zone (CZ) and gasification zone (GZ). Residual char is combusted with air in the $\mathrm{CZ}$ and the heat is transferred to the GZ via circulating bed material. This heat drives the endothermic steam gasification reactions which produce the syn-gas. The raw syn-gas is cooled and then passed through a filter. Tar along with $\mathrm{NH}_{3}$ and $\mathrm{HCl}$ are removed by means of a rapeseed oil methyl ester (RME) scrubber after which the cold clean syn-gas is mixed with air and fed to the gas engine. The DFB gasifier CZ flue gas is cooled then filtered to remove fly ash and then mixed with the cooled gas engine flue gas. The mixed flue gas is directed to the plant stack. Heat is recovered at all stages of cooling to cover the plant air preheating, steam generation and district heating requirements. A more detailed description of the process can be found in the literature [5, 10, 27]

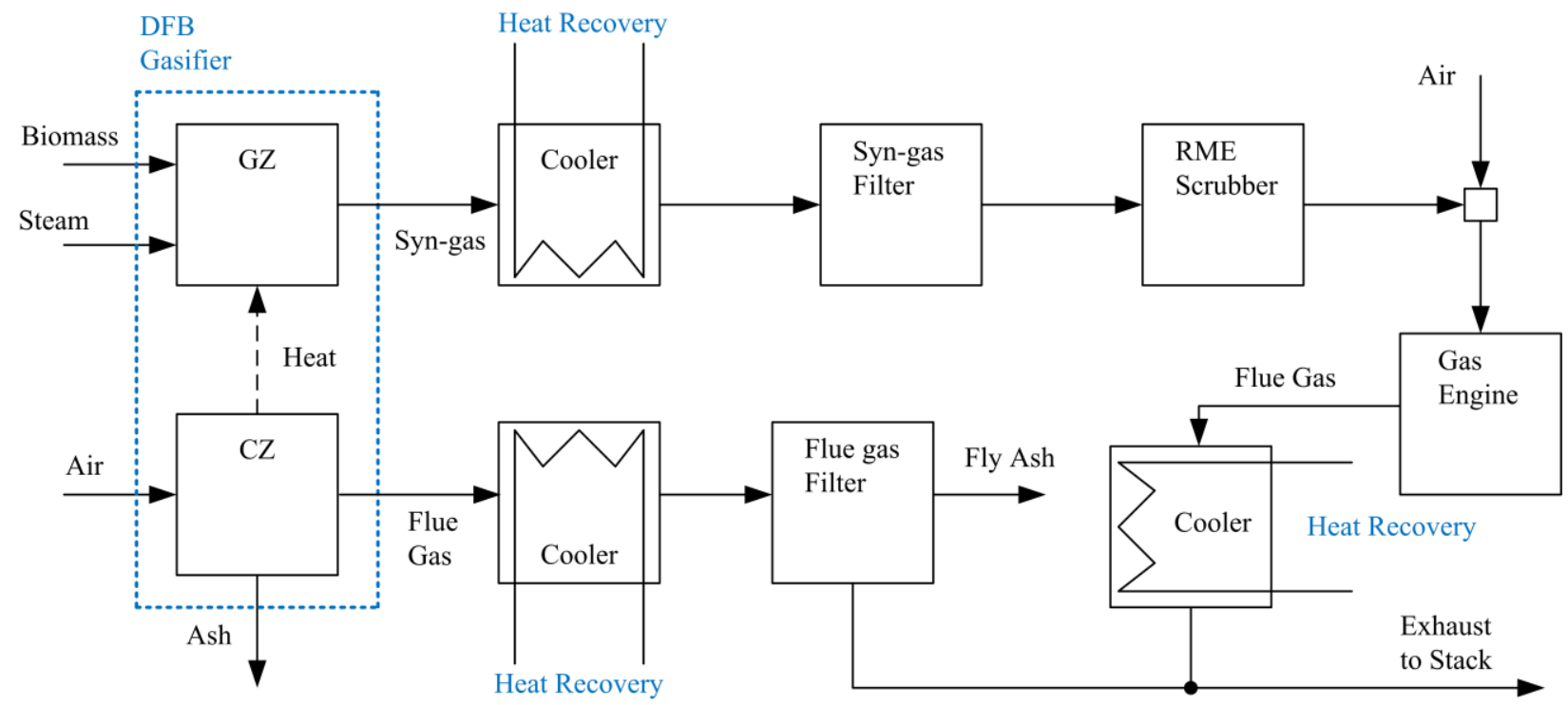

Fig. 2. Güssing CHP plant flow diagram.

\subsection{Simulation software}

Aspen Plus was selected for modelling the SOFC. This simulation package has been used for modelling fuel cell power generation systems in many studies $[3,4,7,8,22,28-30]$. It is a steady state chemical process simulator, 
which was developed at Massachusetts Institute of Technology for the US Department of Energy, to evaluate synthetic fuel technologies. It uses unit operation blocks, which are models of specific process operations (reactors, heaters, pumps etc.). The user places these blocks on a flowsheet, specifying material and energy streams. An extensive built in physical properties database is used for the simulation calculations. Aspen Plus has the capability to incorporate Fortran code, written by the user, into the model.

\section{SOFC stack modelling}

\subsection{Model flowsheet}

The Aspen Plus flowsheet of the SOFC stack is depicted in Fig. 3. Table 1 presents a brief description of the unit operation blocks shown in Fig. 3. It gives the Aspen Plus name, that is the name given to each unit operation block by the software developers, the block ID, which is the name given to each block by the user and a short description.

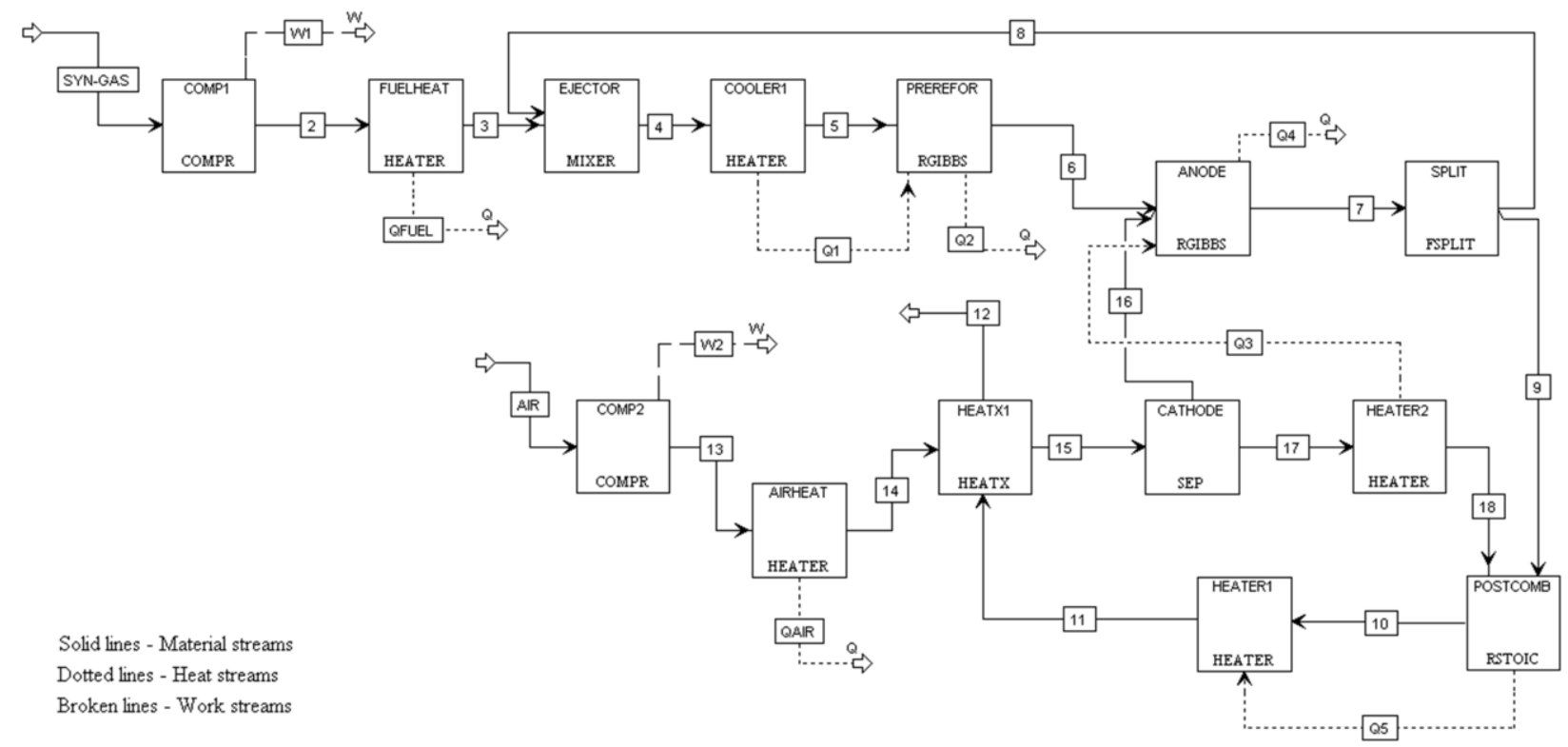

Fig. 3. SOFC stack Aspen Plus flowsheet. 


\section{Table 1}

Description of Aspen Plus flowsheet unit operation blocks presented in Fig. 3.

\begin{tabular}{|c|c|c|}
\hline Aspen Plus name & Block ID & Description \\
\hline \multirow[t]{2}{*}{ Compr } & COMP1 & $\begin{array}{l}\text { Compressor - increases the pressure of the input fuel to a sufficient level } \\
\text { to drive the ejector process }\end{array}$ \\
\hline & COMP2 & $\begin{array}{l}\text { Compressor - increases the pressure of the input oxidant slightly above } \\
\text { atmospheric pressure }\end{array}$ \\
\hline \multirow[t]{5}{*}{ Heater } & FUELHEAT & Heater - preheats the incoming fuel \\
\hline & AIRHEAT & Heater - preheats the incoming air \\
\hline & COOLER1 & $\begin{array}{l}\text { Cooler-decreases the temperature of the mixed fuel to the calculated } \\
\text { pre-reforming temperature }\end{array}$ \\
\hline & HEATER1 & Heater - increases the temperature of the combustion plenum products \\
\hline & HEATER2 & $\begin{array}{l}\text { Heater - increases the temperature of the depleted oxidant stream to the } \\
\text { SOFC operating temperature }\end{array}$ \\
\hline Mixer & EJECTOR & $\begin{array}{l}\text { Mixer - simulates mixing of the recycled depleted fuel with fresh fuel in } \\
\text { the ejector }\end{array}$ \\
\hline \multirow[t]{2}{*}{ RGibbs } & PREREFOR & $\begin{array}{l}\text { Gibbs free energy reactor - simulates steam reforming of higher } \\
\text { hydrocarbons and } \mathrm{CH}_{4} \text { and the shifting of } \mathrm{CO} \text { to } \mathrm{H}_{2}\end{array}$ \\
\hline & ANODE & Gibbs free energy reactor - simulates the reactions occurring at the anode \\
\hline FSplit & SPLIT & $\begin{array}{l}\text { Splitter - splits the depleted fuel into a recycle stream sent to the ejector } \\
\text { and a stream sent to the combustion plenum }\end{array}$ \\
\hline RStoic & POSTCOMB & $\begin{array}{l}\text { Stoichiometric reactor - simulates the complete combustion of the } \\
\text { remaining fuel with the depleted oxidant }\end{array}$ \\
\hline HeatX & HEATX1 & $\begin{array}{l}\text { Heat exchanger - simulates preheating of the oxidant through the injector } \\
\text { tube wall by the combustion of the depleted fuel }\end{array}$ \\
\hline Sep & CATHODE & Separator - separates the $\mathrm{O}_{2}$ required by the electrochemical reaction \\
\hline
\end{tabular}

\subsection{Model description}

The model is based on the following main assumptions: isothermal and steady state operation; zerodimensional; all working fluids treated as ideal gases; pressure drops are neglected; adiabatic pre-reformers; reforming and shift reactions reach chemical equilibrium; ion cross over through the electrolyte cannot be modelled in Aspen Plus, therefore the overall oxidation of $\mathrm{H}_{2}$ (Eq. (3)) was considered instead of the cell half reactions; and only $\mathrm{H}_{2}$ is reacted electrochemically, it is assumed that $\mathrm{CO}$ is shifted to $\mathrm{H}_{2}$ and $\mathrm{CH}_{4}$ is reformed to $\mathrm{H}_{2}$ [4, 22, 31, 32].

Referring to Fig. 3, the stream 'SYN-GAS' is fed to the 'COMP1' block, simulating syn-gas compression. The discharge pressure was calculated using a pressure ratio: $P_{\text {syngas }} / P_{\text {SOFC }}=3$ [16]. The syn-gas composition, temperature and pressure were entered; its mole flow rate is set by a design specification block and depends on the specified stack power (or for variable power a calculator block sets the mole flow depending on the specified $j$ ). The pressurised syn-gas is brought up to the preheat temperature in the block 'FUELHEAT' and its exit stream enters the 'EJECTOR' block, where it is mixed with the recycled depleted fuel (stream 8). The blocks 'COOLER1' and 'PREREFOR' represent the stack pre-reformers. The purpose of 'COOLER1' is to set the pre-reforming 
temperature. It is calculated by means of a design specification block, which varies the temperature of 'COOLER1' until the net heat duty of 'PREREFOR' equals zero (adiabatic). As a result, the gas is cooled simulating the endothermicity of the steam reforming process. The following reactions (Eqs. (1) and (2)), assumed to reach equilibrium at the pre-reforming temperature, were specified in the 'PREREFOR' block:

Steam reforming:

$$
\mathrm{C}_{x} \mathrm{H}_{y}+x \mathrm{H}_{2} \mathrm{O} \leftrightarrow(y / 2+x) \mathrm{H}_{2}+x \mathrm{CO}
$$

Water-gas shift:

$\mathrm{CO}+\mathrm{H}_{2} \mathrm{O} \leftrightarrow \mathrm{CO}_{2}+\mathrm{H}_{2}$

Overall reaction:

$$
\mathrm{H}_{2}+0.5 \mathrm{O}_{2} \rightarrow \mathrm{H}_{2} \mathrm{O}
$$

The pre-reformed fuel (stream 6) is fed to the 'ANODE' block, where the remaining $\mathrm{CH}_{4}$ is reformed, $\mathrm{CO}$ is shifted and $\mathrm{H}_{2}$ is oxidised. The transfer of ions cannot be modelled in Aspen Plus; therefore the overall reaction (Eq. (3)) instead of the cell half reactions was used in the model. Although it is possible to directly oxidise $\mathrm{CH}_{4}$ and $\mathrm{CO}$ in a SOFC at its high operating temperature, it is common to assume that the $\mathrm{CH}_{4}$ is reformed and the $\mathrm{CO}$ is shifted to $\mathrm{H}_{2}$ and therefore only $\mathrm{H}_{2}$ participates in the electrochemical reaction. Equations (1), (2) and (3) were specified in the 'ANODE' block and it was assumed that they reach equilibrium at the block temperature $\left(T_{o p}=1183.15 \mathrm{~K}\right)$. The stream 'AIR' is fed to the 'COMP2' block, the air compressor and its discharge pressure was set as slightly above atmospheric pressure $\left(P_{S O F C}\right)$. The air stream composition, temperature and pressure were entered. The molar flow rate is set using a design specification block that varies the air flow until the air utilisation factor $U_{a}=16.7 \%$ [7]. The compressed air is brought up to the air preheat temperature in the block 'AIRHEAT' and its exit stream enters 'HEATX1' where it is preheated further by the hot combustion plenum products. The compressed and preheated air (stream 15) enters the 'CATHODE' block, whose function is to separate out the $\mathrm{O}_{2}$ required for the electrochemical reaction $\left(n \mathrm{O}_{2, \text { consumed }}\right)$. The 'CATHODE' block $\mathrm{O}_{2}$ split fraction $\left(O_{2, \text { split }}\right)$ is set by a calculator block using the following equations:

$$
\begin{aligned}
& n H_{2, \text { in }}=n H_{2, \text { syn-gas }}+1\left(n \mathrm{CO}_{\text {syn-gas }}\right)+4\left(n \mathrm{CH}_{4, s y n-\text { gas }}\right)+\ldots \\
& U_{f}=\frac{n H_{2, \text { consumed }}}{n H_{2, \text { in }}} \\
& n O_{2, \text { consumed }}=0.5 n H_{2, \text { consumed }}
\end{aligned}
$$


$O_{2, \text { split }}=\frac{n O_{2, \text { consumed }}}{n O_{2, \text { in }}}$

$n H_{2, \text { in }}$ is calculated, where $n H_{2, \text { syn-gas }}$ is the molar flow rate of $\mathrm{H}_{2}$ contained in 'SYN-GAS'; $1\left(n C O_{\text {syn-gas }}\right)$ is the molar flow rate of $\mathrm{H}_{2}$ that could be produced from the $\mathrm{CO}$ in 'SYN-GAS'; $4\left(\mathrm{nCH}_{4, \text { syn-gas }}\right)$ is the molar flow rate of $\mathrm{H}_{2}$ that could be produced from the $\mathrm{CH}_{4}$ in 'SYN-GAS' and the same applies to the higher hydrocarbons. Next $n H_{2, \text { consumed }}$ is determined with known $U_{f}$ (typical value 0.85). $n O_{2, \text { consumed }}$ is then found using Eq. (6) and finally $O_{2, \text { split }}$ is calculated using Eq. (7). It is worth noting that $O_{2, s p l i t}$ is equivalent to $U_{a}$. The required $\mathrm{O}_{2}$ is directed to the 'ANODE' block (stream 16). The temperature of the depleted air (stream 17) must be increased to $T_{o p}$. The heat needed to do this is supplied by the electrochemical reaction and this process was simulated by taking a heat stream (Q3) from 'HEATER2' to 'ANODE'. The temperature of the 'HEATER2' block was specified as $1183.15 \mathrm{~K}\left(T_{o p}\right)$. The depleted fuel (stream 7) enters the block 'SPLIT', whose function is to split the stream into a recycle (stream 8) and a stream directed to the combustion plenum. The split fraction of the block is set using a design specification block where it is determined by a specified STCR, defined as the molar ratio of steam to combustible carbon [13], a typical value being 2.5. The depleted fuel and oxidant are fed to 'POSTCOMB' where complete combustion of the remaining fuel occurs. The heat generated by the combustion reactions is represented by the heat stream Q5, which is fed to the block 'HEATER1', whose function is to calculate and set the combustion products temperature. Finally, the high temperature combustion products (stream 11) exchange heat with and serve to preheat the incoming air in the 'HEATX1' block. The temperature of the SOFC stack exhaust (stream 12) is also determined.

\subsection{Voltage calculation}

The voltage was calculated by first applying the widely known Nernst equation (Eq. (8)) to determine the reversible Nernst voltage $\left(V_{N}\right)$ and then subtracting the various losses, including ohmic, activation and concentration losses. In Eq. (8) $\Delta \bar{g}_{f}$ is the molar Gibbs free energy of formation ( $\left.\mathrm{J} / \mathrm{mol}\right)$ at standard pressure (1 bar), 2 represents the number of electrons produced per mole of $\mathrm{H}_{2}$ fuel reacted, $F$ is the Faraday constant $(96485 \mathrm{C} / \mathrm{mol}), T_{a v g}$ is the average temperature between the SOFC inlet and outlet streams $(\mathrm{K}), R_{g}$ is the molar gas constant and was taken as $8.314 \mathrm{~J} / \mathrm{mol} \mathrm{K}$ and $P_{i}$ is the partial pressure (in bar) of gaseous component $i$. The partial pressures were taken as average values of the anode and cathode inlet and outlet streams. 


$$
V_{N}=-\frac{\Delta \bar{g}_{f}}{2 \cdot F}+\frac{R_{g} \cdot T_{a v g}}{2 \cdot F} \ln \frac{P_{H_{2}} \cdot P_{O_{2}}^{0.5}}{P_{\mathrm{H}_{2} \mathrm{O}}}
$$

The ohmic loss, which is the voltage loss due to the resistance to electron flow through both electrodes and the interconnection and the resistance to ion flow through the electrolyte, was calculated using Eqs. (9) - (12), shown in Table 2. These equations developed by Song et al. [23] take into account realistic electron/ion paths in a tubular SOFC and they have been used in many studies to simulate the ohmic loss for SPGI tubular SOFC systems $[6,23,33]$. They assumed uniform current density in the circumferential direction and uniform ionic flux in the electrolyte in the radial direction. The angle related to the extent of electrical contact is $A \pi$ radians while the angle $B \pi$ radians is related to the interconnection. The resistivity terms $\left(\rho_{A}, \rho_{C}, \rho_{E}\right.$ and $\left.\rho_{\text {Int }}\right)$ were determined using the temperature dependent relations proposed by Bessette et al. [14], given in Table 3. Other terms that appear in Eqs. (9) - (12) include $D_{m}$, which is the mean diameter of a cell (m), calculated from the geometry parameters given in Table 3, the cell component thickness $t(\mathrm{~m})$ and the interconnection width $w_{I n t}(\mathrm{~m})$. The ohmic loss is especially important for tubular SOFCs as it is the dominant loss due to long current flow paths.

\section{Table 2}

Voltage loss equations.

\begin{tabular}{|c|c|c|}
\hline \multicolumn{3}{|l|}{ Ohmic loss } \\
\hline Anode & $V_{\text {Ohm }-A}=\frac{j \cdot \rho_{A}\left(A \cdot \pi \cdot D_{m}\right)^{2}}{8 \cdot t_{A}}$ & (9) \\
\hline Cathode & $V_{\text {ohm }_{-} C}=\frac{j \cdot \rho_{C}\left(\pi \cdot D_{m}\right)^{2}}{8 \cdot t_{C}} \cdot A[A+2(1-A-B)]$ & (10) \\
\hline Electrolyte & $V_{\text {otm }_{E} E}=j \cdot \rho_{E} \cdot t_{E}$ & (11) \\
\hline Interconnection & $V_{o h m \_l n t}=j \cdot \rho_{l n t}\left(\pi \cdot D_{m}\right) \frac{t_{l h t}}{w_{l h t}}$ & (12) \\
\hline \multicolumn{3}{|l|}{ Activation loss } \\
\hline Anode & $\frac{1}{R_{A c t} A}=\frac{2 \cdot F}{R_{g} \cdot T_{o p}} \cdot k_{A}\left(\frac{P_{H_{2}}}{P^{0}}\right)^{m} \exp \left(\frac{-E_{A}}{R_{g} \cdot T_{o p}}\right)$ & (13) \\
\hline Cathode & $\frac{1}{R_{A t_{-} C}}=\frac{4 \cdot F}{R_{g} \cdot T_{o p}} \cdot k_{C}\left(\frac{P_{O_{2}}}{P^{0}}\right)^{m} \exp \left(\frac{-E_{C}}{R_{g} \cdot T_{o p}}\right)$ & (14) \\
\hline \multicolumn{3}{|c|}{ Concentration loss } \\
\hline Anode & 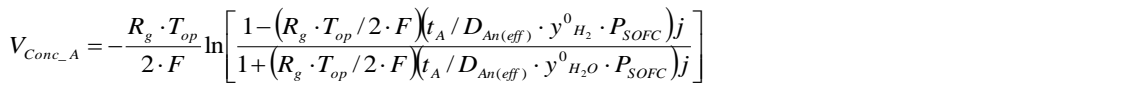 & (15) \\
\hline Cathode & $V_{\text {Conc } C}=-\frac{R_{g} \cdot T_{\text {op }}}{4 \cdot F} \ln \left\{\frac{\left(P_{\text {SOFC }} / \delta_{O_{2}}\right)-\left[\left(P_{\text {SOFC }} / \delta_{O_{2}}\right)-y^{0} O_{2} \cdot P_{\text {SOFC }}\right] \exp \left[\left(R_{g} \cdot T_{\text {op }} / 4 \cdot F\right)\left(\delta_{O_{2}} \cdot t_{C} / D_{\text {Careff } f} \cdot P_{\text {SOFC }}\right) j\right]}{y^{0} o_{2} \cdot P_{\text {SOFC }}}\right\}$ & (16) \\
\hline
\end{tabular}


The activation loss due to slow or sluggish kinetics of the electrochemical reaction taking place on the electrodes was determined using the semi-empirical correlations proposed by Achenbach [24], Eqs. (13) and (14). It is the voltage lost as a result of the energy barrier that must be overcome by the reacting species. In Eqs. (13) and (14) the $R_{\text {Act }}$ terms represent specific resistance $\left(\Omega \mathrm{m}^{2}\right)$ at both anode and cathode. The activation voltage loss $V_{A c t}$ was evaluated by multiplying the specific resistance terms by $j\left(\mathrm{~A} / \mathrm{m}^{2}\right)$. The pre-exponential factors $k_{A}$ and $k_{C}$ are listed in Table 3. The partial pressures $P_{i}$ (bar) were taken as average values of the anode and cathode inlet and outlet streams. $P^{0}$ is a reference pressure and was taken as 1 bar; the influence of partial pressure is accounted for by the slope $m$. The $E$ terms are activation energies and are listed in Table 3 . The activation voltage loss is less significant in SOFCs compared to other fuel cells due to the high operating temperature.

\section{Table 3}

Model input parameters.

\begin{tabular}{|c|c|}
\hline \multicolumn{2}{|l|}{ Geometry [19, 34-36] } \\
\hline Cell length / diameter (m) & $1.5 / 0.022$ \\
\hline Anode thickness $t_{A}(\mathrm{~m})$ & 0.0001 \\
\hline Cathode thickness $t_{C}(\mathrm{~m})$ & 0.0022 \\
\hline Electrolyte thickness $t_{E}(\mathrm{~m})$ & 0.00004 \\
\hline $\begin{array}{l}\text { Interconnection } \\
\text { thickness } t_{\text {Int }}(\mathrm{m})\end{array}$ & 0.000085 \\
\hline Interconnection width $w_{\text {Int }}(\mathrm{m})$ & 0.009 \\
\hline \multicolumn{2}{|l|}{ Material properties } \\
\hline Anode resistivity & $2.98 \times 10^{-5}$ \\
\hline$\rho_{A}(\Omega \mathrm{m})[14]$ & $\exp \left(-1392 / T_{o p}\right)$ \\
\hline Cathode resistivity & $8.114 \times 10^{-5}$ \\
\hline$\rho_{C}(\Omega \mathrm{m})[14]$ & $\exp \left(600 / T_{o p}\right)$ \\
\hline Electrolyte resistivity & $2.94 \times 10^{-5}$ \\
\hline$\rho_{E}(\Omega \mathrm{m})[14]$ & $\exp \left(10350 / T_{o p}\right)$ \\
\hline Interconnection resistivity & 0.025 \\
\hline \multicolumn{2}{|l|}{$\rho_{\text {Int }}(\Omega \mathrm{m})[19]$} \\
\hline \multicolumn{2}{|l|}{ Ohmic loss [23] } \\
\hline$A / B$ & $0.804 / 0.13$ \\
\hline \multicolumn{2}{|l|}{ Activation loss $[24,32]$} \\
\hline $\begin{array}{l}\text { Pre-exponential factor } k_{A} / k_{C} \\
\left(\mathrm{~A} / \mathrm{m}^{2}\right)\end{array}$ & $\begin{array}{l}2.13 \times 10^{8} / \\
1.49 \times 10^{10}\end{array}$ \\
\hline Slope $m$ & 0.25 \\
\hline Activation energy $E_{A} / E_{C}(\mathrm{~J} / \mathrm{mol})$ & $110000 / 160000$ \\
\hline \multicolumn{2}{|l|}{ Concentration loss } \\
\hline Electrode pore radius $r(\mathrm{~m})$ [25] & $5 \times 10^{-7}$ \\
\hline $\begin{array}{l}\text { Electrode porosity } \varepsilon / \\
\text { tortuosity } \xi[37]\end{array}$ & $0.5 / 5.9$ \\
\hline
\end{tabular}


The concentration loss due to mass transfer limitations in the porous electrodes was modelled using Eqs. (15) and (16) [25]. Diffusion transport in the electrodes (gases in pores) was considered with convection in the gas channel neglected. Equations (15) and (16) were derived using Fick's law of diffusion and both ordinary and Knudsen diffusion were considered. Ordinary diffusion occurs when the pore diameter of the material is large in comparison to the mean free path of the gas molecules, whereas Knudsen diffusion occurs when the pores are small [25]. Both types of diffusion were accounted for by calculating effective diffusion coefficients for the anode and cathode. The following equations were used to determine the Knudsen diffusion and effective Knudsen diffusion coefficients for the anode and cathode gases:

$$
\begin{aligned}
& D_{K, i}=97 r\left(T_{o p} / M_{i}\right)^{0.5} \\
& D_{K, i(e f f)}=D_{K, i}(\varepsilon / \xi)
\end{aligned}
$$

where subscript $i$ represents the gaseous component $\left(\mathrm{H}_{2}, \mathrm{H}_{2} \mathrm{O}, \mathrm{O}_{2}\right.$ or $\left.\mathrm{N}_{2}\right), r$ is the electrode pore radius (m) given in Table $3, M_{i}$ is the molecular weight $(\mathrm{kg} / \mathrm{kmol})$ of the gaseous component, $\varepsilon$ is porosity and $\xi$ is tortuosity of the electrodes (Table 3). The most common method for theoretical estimation of ordinary binary diffusion coefficients is the one developed independently by Chapman and Enskog [38]. Todd and Young [39] investigated the performance of four of the most used ordinary binary diffusion coefficient estimation techniques, the Chapman-Enskog and Fuller et al. [40] methods among them. From comparing predictions with available experimental data they concluded that the Fuller et al. [40] method, which is by far the simplest, performs best with an estimated mean error of 5\%. Based on these findings the Fuller et al. [40] method (Eq. (19)), which is based on the kinetic theory of gases was used to calculate the ordinary binary diffusion coefficient for both anode and cathode.

$$
D_{i k}=\frac{1 \times 10^{-7} T_{o p}{ }^{1.75}\left(1 / M_{i}+1 / M_{k}\right)^{1 / 2}}{P\left(v_{i}{ }^{1 / 3}+v_{k}{ }^{1 / 3}\right)^{2}}
$$

where subscripts $i$ and $k$ represent the gaseous components that make up the binary gas mixture $\left(\mathrm{H}_{2}-\mathrm{H}_{2} \mathrm{O}\right.$ at the anode and $\mathrm{O}_{2}-\mathrm{N}_{2}$ at the cathode), $P$ is pressure in atmospheres and $v$ is the Fuller diffusion volume, taken as 7.07, 12.7, 16.6 and 17.9 for $\mathrm{H}_{2}, \mathrm{H}_{2} \mathrm{O}, \mathrm{O}_{2}$ and $\mathrm{N}_{2}$ respectively [40]. Similar to the case of Knudsen diffusion, the effective 
ordinary diffusion coefficient is given by Eq. (20). The overall effective diffusion coefficient for each gas was then calculated using Eq. (21).

$D_{i k(e f f)}=D_{i k}(\varepsilon / \xi)$

$1 / D_{i(e f f)}=1 / D_{i k(e f f)}+1 / D_{K, i(e f f)}$

Finally, the anode and cathode diffusion coefficients were calculated using Eqs. (22) and (23) and $\delta_{O 2}$ in Eq. (16) was found using Eq (24).

$$
\begin{aligned}
& D_{A n(e f f)}=\left(\frac{y^{0}{ }_{H_{2} O} \cdot P_{S O F C}}{P_{S O F C}}\right) D_{H_{2}(e f f)}+\left(\frac{y^{0}{ }_{H_{2}} \cdot P_{S O F C}}{P_{S O F C}}\right) D_{H_{2} O(e f f)} \\
& D_{\text {Cat (eff })}=D_{O_{2}(e f f)} \\
& \delta_{O_{2}}=\frac{D_{K, O_{2}(e f f)}}{\left(D_{K, O_{2}(e f f)}+D_{O_{2}-N_{2}(e f f)}\right)}
\end{aligned}
$$

The $y_{i}^{0}$ terms in Eqs. (15) and (16) are the gas molar fractions in the bulk flow, taken as the average values of the anode and cathode inlet and outlet streams. The concentration loss is low unless the current density is high and the fuel and air concentrations are low, caused by high utilisations $\left(U_{f}\right.$ and $\left.U_{a}\right)$. Under these conditions the limiting current may be reached reducing the fuel cell voltage to very low levels.

The actual voltage $V$ was calculated using Eq. (25), which is simply the Nernst voltage less the sum of the voltage losses.

$V=V_{N}-\left(V_{\text {Ohm }}+V_{\text {Act }}+V_{\text {Conc }}\right)$

The calculations described above are carried out using a design specification block, which varies the input fuel flow until the SOFC stack DC power $\left(P_{e l, D C}=V I\right)$ equals a specified value (base case: $\left.120 \mathrm{~kW}\right)$. However, for known current (I), as was the case for the current density sensitivity analysis (section 4.2), a calculator block determines and sets the input fuel flow using: 
$n H_{2, i n}=\frac{I}{2 F U_{f}} \cdot \frac{3600}{1000}$

nFuel $_{\text {in }}=\frac{n H_{2, \text { in }}}{y \mathrm{H}_{2}+y \mathrm{CO}+4 y \mathrm{CH}_{4}+\ldots}$

where $n F u e l_{\text {in }}$ is the input fuel flow $(\mathrm{kmol} / \mathrm{s})$ and $y_{i}$ is the molar fraction of gaseous component $i$ in the input fuel.

The voltage and DC power are then calculated.

\subsection{Model validation}

\subsubsection{Validation: fuel number one}

The model was validated against published data for the SPGI $100 \mathrm{~kW}$ CHP SOFC stack operating on natural gas. The model inputs were as follows [16, 22]:

- Natural gas composition (mole fraction): $\mathrm{CH}_{4}$ 0.813, $\mathrm{C}_{2} \mathrm{H}_{6} 0.029, \mathrm{C}_{3} \mathrm{H}_{8} \quad 0.004, \mathrm{C}_{4} \mathrm{H}_{10} 0.002, \mathrm{~N}_{2} 0.143, \mathrm{CO}_{2}$ 0.009 .

- $\quad$ Operating pressure $\left(P_{S O F C}\right)$ / ejector pressure ratio: $109431 \mathrm{~Pa} / 3$.

- $\quad$ Active area $(S): 96.0768 \mathrm{~m}^{2}$ (1152 cells).

- Operating / electrodes exhaust temperature $\left(T_{o p}\right): 1183.15 \mathrm{~K}$.

- Input air / fuel temperature: $630 / 200{ }^{\circ} \mathrm{C}$.

- $\quad U_{f} / U_{a} / S T C R: 0.85 / 0.19 / 1.8$.

- Cold and hot stream temperature difference (recuperator 'HEATX1'): $10^{\circ} \mathrm{C}$.

- $\quad$ DC power $\left(P_{e l, D C}\right): 120 \mathrm{~kW}$.

- DC to AC inverter efficiency: $92 \%$.

\section{Table 4}

Model results compared to literature (validation: fuel number one).

\begin{tabular}{lll}
\hline & Literature [22] & Model results \\
\hline Voltage $(\mathrm{mV})$ & 700 & 683 \\
Current density $\left(\mathrm{mA} / \mathrm{cm}^{2}\right)$ & 178 & 182.86
\end{tabular}




\begin{tabular}{|c|c|c|}
\hline Pre-reforming temperature $(\mathrm{K})$ & 809.15 & 808.25 \\
\hline Pre-reformer $\mathrm{CH}_{4}$ conversion (\%) & 25.9 & 25 \\
\hline Cathode inlet temperature $(\mathrm{K})$ & 1094.47 & 1096.85 \\
\hline Combustion products temperature $(\mathrm{K})$ & 1285.5 & 1285.45 \\
\hline Stack exhaust temperature $(\mathrm{K})$ & 1107 & 1106.85 \\
\hline $\begin{array}{l}\text { Anode inlet gas composition } \\
(\text { mole \%) }\end{array}$ & $\begin{array}{l}\mathrm{H}_{2} 27, \mathrm{CO} 5.6, \mathrm{CH}_{4} 10.1, \\
\mathrm{H}_{2} \mathrm{O} 27.9, \mathrm{CO}_{2} 23.1, \mathrm{~N}_{2} 6.2\end{array}$ & $\begin{array}{l}\mathrm{H}_{2} 26.9, \mathrm{CO} 5.6, \mathrm{CH}_{4} 10.4, \\
\mathrm{H}_{2} \mathrm{O} 27.8, \mathrm{CO}_{2} 23.1, \mathrm{~N}_{2} 6.2\end{array}$ \\
\hline $\begin{array}{l}\text { Anode exhaust gas composition } \\
\text { (mole \%) }\end{array}$ & $\begin{array}{l}\mathrm{H}_{2} 11.6, \mathrm{CO} 7.4, \mathrm{H}_{2} \mathrm{O} 50.9 \\
\mathrm{CO}_{2} 24.9, \mathrm{~N}_{2} 5.1\end{array}$ & $\begin{array}{l}\mathrm{H}_{2} 11.6, \mathrm{CO} 7.4, \mathrm{H}_{2} \mathrm{O} 50.9, \\
\mathrm{CO}_{2} 24.9, \mathrm{~N}_{2} 5.1\end{array}$ \\
\hline $\begin{array}{l}\text { Cathode exhaust gas composition } \\
\text { (mole \%) }\end{array}$ & $\mathrm{O}_{2} 17.7, \mathrm{~N}_{2} 82.3$ & $\mathrm{O}_{2} 17.7, \mathrm{~N}_{2} 82.3$ \\
\hline $\begin{array}{l}\text { Stack exhaust gas composition } \\
\text { (mole \%) }\end{array}$ & $\begin{array}{l}\mathrm{H}_{2} \mathrm{O} 4.5, \mathrm{CO}_{2} 2.3 \\
\mathrm{O}_{2} 15.9, \mathrm{~N}_{2} 77.3\end{array}$ & $\begin{array}{l}\mathrm{H}_{2} \mathrm{O} 4.5, \mathrm{CO}_{2} 2.3 \\
\mathrm{O}_{2} 15.9, \mathrm{~N}_{2} 77.3\end{array}$ \\
\hline Gross AC efficiency (LHV) (\%) & 52 & 51.28 \\
\hline Net AC efficiency (LHV) (\%) & $\mathrm{nr}^{\mathrm{a}}$ & 49.15 \\
\hline
\end{tabular}

${ }^{\mathrm{a}} \mathrm{nr}=$ not reported.

As seen in Table 4, the model results are in good agreement with published work. There is only a slight difference for voltage, current density and efficiency. The reader should note that Zhang et al. [22] used a very different method for calculating the voltage to the one applied in this work. They used semi-empirical correlations developed using a reference polarisation curve. It has been reported that these correlations may not be valid for other fuels [41]. The method of voltage calculation applied in this work is considered to be more rigorous as the equations employed consider changes in temperature, pressure, gas molar fractions, cell geometry and material properties and therefore they may be applied to diverse fuels. Some other differences in comparison with the work of Zhang et al. [22] include the manner in which the oxidant flow rate is set, in this work it is set using a specified $U_{a}$ whereas in Zhang et al. [22] they apply a heat balance assuming a certain amount of heat loss. Finally, in this work the fuel and air compressors are modelled, which permits the calculation of the stack parasitic power requirement and the net AC efficiency. For comparison, Campanari [16] reports a voltage and current density of $690 \mathrm{mV}$ and $180 \mathrm{~mA} / \mathrm{cm}^{2}$ and a net AC efficiency of $48.5 \%$. These results compare well with this work. The gross and net AC efficiencies are defined as:

$$
\begin{gathered}
\eta_{e l, \text { gross }}=\frac{P_{e l, A C}}{n F u e l_{\text {in }} \cdot L H V_{\text {fuel }}} \\
\eta_{e l, \text { net }}=\frac{P_{e l, A C}-P_{c o m p}}{n F u e l_{\text {in }} \cdot L H V_{f u e l}}
\end{gathered}
$$


where $P_{e l, A C}$ is the AC power $(\mathrm{kW}), n F u e l_{\text {in }}$ is the molar flow rate of input fuel $(\mathrm{kmol} / \mathrm{s}), L H V_{\text {fuel }}$ is the lower heating value of the input fuel $(\mathrm{kJ} / \mathrm{kmol})$ and $P_{\text {comp }}$ is the electrical power requirement of the fuel and air compressors $(\mathrm{kW})$.

\subsubsection{Validation: fuel number two}

A second validation of the model was conducted using published data for the SPGI $100 \mathrm{~kW}$ CHP SOFC stack operating on natural gas of different composition and with the stack operating at different conditions compared to the first validation. The model inputs for this validation run were as follows $[16,17,22,42]$ :

- Natural gas composition (mass fraction): $\mathrm{CH}_{4} 0.938, \mathrm{~N}_{2} 0.038, \mathrm{CO}_{2} 0.024$.

- $\quad$ Operating pressure $\left(P_{S O F C}\right)$ / ejector pressure ratio: $109431 \mathrm{~Pa} / 3$.

- $\quad$ Active area $(S): 96.0768 \mathrm{~m}^{2}$ (1152 cells).

- Operating / electrodes exhaust temperature $\left(T_{o p}\right): 1193.15 \mathrm{~K}$.

- Input air / fuel temperature: $20 / 200{ }^{\circ} \mathrm{C}$.

- $\quad U_{f} / U_{a} / S T C R: 0.85 / 0.2 / 2$.

- $\quad$ DC power $\left(P_{e l, D C}\right): 127.4 \mathrm{~kW}$.

- DC to AC inverter efficiency: $92 \%$.

\section{Table 5}

Model results compared to literature (validation: fuel number two).

\begin{tabular}{|c|c|c|}
\hline & Literature $[17,42]$ & Model results \\
\hline Voltage $(\mathrm{mV})$ & 661 & 662.8 \\
\hline Current density $\left(\mathrm{mA} / \mathrm{cm}^{2}\right)$ & $200.6^{\mathrm{a}}$ & 200.62 \\
\hline Pre-reforming temperature $(\mathrm{K})$ & 851.15 & 815.35 \\
\hline Pre-reformer $\mathrm{CH}_{4}$ conversion (\%) & 40 & 35 \\
\hline Cathode inlet temperature $(\mathrm{K})$ & 1155.15 & 1155.15 \\
\hline Combustion products temperature $(\mathrm{K})$ & 1374.15 & 1299.65 \\
\hline Stack exhaust temperature $(\mathrm{K})^{\mathrm{b}}$ & 552.15 & 512.85 \\
\hline $\begin{array}{l}\text { Anode inlet gas composition } \\
(\operatorname{mass} \%)\end{array}$ & $\begin{array}{l}\mathrm{H}_{2} 3.16, \mathrm{CO} 11.2, \mathrm{CH}_{4} 5.81, \\
\mathrm{H}_{2} \mathrm{O} 27.3, \mathrm{CO}_{2} 51.29, \mathrm{~N}_{2} 1.24\end{array}$ & $\begin{array}{l}\mathrm{H}_{2} 2.9, \mathrm{CO} 8.3, \mathrm{CH}_{4} 7.4, \\
\mathrm{H}_{2} \mathrm{O} 27.4, \mathrm{CO}_{2} 52.8, \mathrm{~N}_{2} 1.3\end{array}$ \\
\hline $\begin{array}{l}\text { Anode exhaust gas composition } \\
\text { (mass \%) }\end{array}$ & $\begin{array}{l}\mathrm{H}_{2} 1.39, \mathrm{CO} 11.91, \mathrm{H}_{2} \mathrm{O} 39.88 \\
\mathrm{CO}_{2} 45.88, \mathrm{~N}_{2} 0.94\end{array}$ & $\begin{array}{l}\mathrm{H}_{2} 1.0, \mathrm{CO} 9.2, \mathrm{H}_{2} \mathrm{O} 41.2, \\
\mathrm{CO}_{2} 47.7, \mathrm{~N}_{2} 0.9\end{array}$ \\
\hline $\begin{array}{l}\text { Cathode exhaust gas composition } \\
\text { (mass \%) }\end{array}$ & $\mathrm{nr}^{\mathrm{c}}$ & $\mathrm{O}_{2} 19.6, \mathrm{~N}_{2} 80.4$ \\
\hline
\end{tabular}


Stack exhaust gas composition (mass \%)

Gross AC efficiency (LHV) $(\%)$ Net AC efficiency (LHV) (\%)
$\mathrm{H}_{2} \mathrm{O} 3.14, \mathrm{CO}_{2} 3.87$, $\mathrm{O}_{2} 17.38, \mathrm{~N}_{2} 75.62$

$48^{\mathrm{d}}$ $\mathrm{nr}$
$\mathrm{H}_{2} \mathrm{O}$ 3.0, $\mathrm{CO}_{2}$ 3.7,

$\mathrm{O}_{2} 17.6, \mathrm{~N}_{2} 75.7$

${ }^{\mathrm{a}}$ Calculated assuming an active area of $96.0768 \mathrm{~m}^{2}$.

${ }^{\mathrm{b}}$ Stack exhaust temperature after preheating cathode air to high level (1155.15 K).

${ }^{\mathrm{c}} \mathrm{nr}=$ not reported.

${ }^{\mathrm{d}}$ Calculated using Eq. (28).

The reader should note that the temperature and gas composition data (Table 5) utilised for the second validation were obtained using a 1-D model [42]. It is reported that this model was validated against experiments carried out on a SPGI $100 \mathrm{~kW}$ CHP SOFC stack in Torino, Italy as part of the EOS project. The model predictions are in good agreement with the literature data. The largest discrepancies exist for the combustion products temperature and the stack exhaust temperature. Both of these temperatures were taken from the model predictions reported in Verda and Quaglia [42]. The actual experimental temperatures presented in that article [42] match this works model predictions more closely. The measured average combustion products temperature and stack exhaust temperature were $1297.15 \mathrm{~K}$ and $519.15 \mathrm{~K}$ respectively, which compare very well with this work.

\section{Results and discussion}

The validated model was run using the following syn-gas composition: $45.8 \% \mathrm{H}_{2}, 21.6 \% \mathrm{CO}, 10.0 \% \mathrm{CH}_{4}$, 21.2\% $\mathrm{CO}_{2}, 1.4 \% \mathrm{~N}_{2}$ (volume $\%$, dry basis) and $25.7 \% \mathrm{H}_{2} \mathrm{O}$ (volume $\%$, wet basis) [5]. This syn-gas composition is typical of the Güssing DFB gasifier operating at $850{ }^{\circ} \mathrm{C}$ with a steam/fuel ratio of 0.75 and after gas cleaning. Comparing operation on Güssing biomass syn-gas to natural gas operation (see section 3.4 .1 ) at $j=182.86 \mathrm{~mA} / \mathrm{cm}^{2}$, voltage decreased by $14 \mathrm{mV}$ to $669 \mathrm{mV}$, DC power dropped $2.43 \mathrm{~kW}$ to $117.57 \mathrm{~kW}$ and the gross and net AC efficiency reduced $8.28 \%$ and $11.63 \%$ to $43 \%$ and $37.52 \%$ respectively. The relatively large drop in efficiency is attributed to increased input fuel and air flow, which is due to the lower quality of the fuel gas. Even with this performance decrease the efficiency achieved is much higher than traditional biomass systems, making this technology very promising.

For a required DC power of $120 \mathrm{~kW}$ using base case data (the same as for model validation with the following exceptions: input fuel temperature $=300{ }^{\circ} \mathrm{C}, U_{a}=16.7 \%$ and $S T C R=2.5$ ) and biomass syn-gas fuel the SOFC stack performance was as follows: $j=188.7 \mathrm{~mA} / \mathrm{cm}^{2}, V=662 \mathrm{mV}, \eta_{\text {el,gross }}=42.53 \%$ and $\eta_{e l, \text { net }}=37.04 \%$. These have been identified as realistic design operating conditions with regard to stack performance for operation on 
Güssing biomass syn-gas. The detailed stream results for these operating conditions are presented in Table 6. In addition, the power requirement of the fuel and air compressors was $10.56 \mathrm{~kW}$ and $3.69 \mathrm{~kW}$ respectively. The developed model was used to perform sensitivity analyses in order to give insight into the influence of the main variables on the system and to investigate off-design performance. The effects of varying $U_{f}, j$ and $S T C R$ on SOFC stack performance were investigated.

\section{Table 6}

Detailed stream results for realistic design operating conditions on biomass syn-gas (streams presented in Fig. 3).

\begin{tabular}{|c|c|c|c|c|c|c|c|c|c|c|}
\hline \multirow[t]{2}{*}{ Stream } & \multirow{2}{*}{$\begin{array}{l}\text { Temperature } \\
\left({ }^{\circ} \mathrm{C}\right)\end{array}$} & \multirow{2}{*}{$\begin{array}{l}\text { Pressure } \\
\text { (bar) }\end{array}$} & \multirow{2}{*}{$\begin{array}{l}\text { Mole flow } \\
(\mathrm{kmol} / \mathrm{h})\end{array}$} & \multicolumn{7}{|c|}{ Mole fraction } \\
\hline & & & & $\mathrm{H}_{2}$ & $\mathrm{~N}_{2}$ & $\mathrm{O}_{2}$ & $\mathrm{H}_{2} \mathrm{O}$ & $\mathrm{CO}$ & $\mathrm{CO}_{2}$ & $\mathrm{CH}_{4}$ \\
\hline SYN-GAS & 200.0 & 1.013 & 4.986 & 0.340 & 0.010 & - & 0.257 & 0.160 & 0.158 & 0.074 \\
\hline AIR & 24.9 & 1.013 & 48.358 & - & 0.790 & 0.210 & - & - & - & - \\
\hline 3 & 300.0 & 3.282 & 4.986 & 0.340 & 0.010 & - & 0.257 & 0.160 & 0.158 & 0.074 \\
\hline 4 & 573.3 & 1.094 & 8.397 & 0.227 & 0.010 & - & 0.391 & 0.112 & 0.215 & 0.044 \\
\hline 5 & 571.4 & 1.094 & 8.397 & 0.227 & 0.010 & - & 0.391 & 0.112 & 0.215 & 0.044 \\
\hline 6 & 571.4 & 1.094 & 8.531 & 0.294 & 0.010 & - & 0.331 & 0.072 & 0.258 & 0.036 \\
\hline 7 & 910.0 & 1.094 & 9.138 & 0.062 & 0.009 & - & 0.587 & 0.042 & 0.300 & - \\
\hline 8 & 910.0 & 1.094 & 3.41 & 0.062 & 0.009 & - & 0.587 & 0.042 & 0.300 & - \\
\hline 9 & 910.0 & 1.094 & 5.727 & 0.062 & 0.009 & - & 0.587 & 0.042 & 0.300 & - \\
\hline 10 & 910.0 & 1.094 & 52.096 & - & 0.734 & 0.157 & 0.071 & - & 0.038 & - \\
\hline 11 & 994.1 & 1.094 & 52.096 & - & 0.734 & 0.157 & 0.071 & - & 0.038 & - \\
\hline 12 & 829.7 & 1.094 & 52.096 & - & 0.734 & 0.157 & 0.071 & - & 0.038 & - \\
\hline 14 & 630.0 & 1.094 & 48.358 & - & 0.790 & 0.210 & - & - & - & - \\
\hline 15 & 819.7 & 1.094 & 48.358 & - & 0.790 & 0.210 & - & - & - & - \\
\hline 16 & 819.7 & 1.094 & 1.691 & - & - & 1.000 & - & - & - & - \\
\hline 17 & 819.7 & 1.094 & 46.667 & - & 0.819 & 0.181 & - & - & - & - \\
\hline 18 & 910.0 & 1.094 & 46.667 & - & 0.819 & 0.181 & - & - & - & - \\
\hline
\end{tabular}

\subsection{Sensitivity analysis: fuel utilisation factor}

The influence of $U_{f}$ on SOFC stack performance is depicted in Fig. 4. The cell voltage decreases slightly with $U_{f}$ due to increased voltage losses (ohmic, activation and concentration). The current density increases slightly due to the higher amount of $\mathrm{H}_{2}$ consumed on the anode $\left(I=2 \mathrm{FnH}_{2, \text { consumed }}\right)$. The fuel flow rate required to achieve the desired power $\left(120 \mathrm{~kW} \mathrm{DC)}\right.$ decreases with $U_{f}$. This is because more of the energy contained in the fuel is converted to electricity rather than heat due to the higher $\mathrm{H}_{2}$ consumed by the electrochemical reaction. Efficiency was found to be very sensitive to changes in $U_{f}, \eta_{e l, g r o s s}$ and $\eta_{e l, n e t}$ increase by 18.6 and 17.96 percentage points respectively over the $U_{f}$ range. This is primarily due to the reduced fuel flow rate at high $U_{f}$. The decrease in cell voltage and 
strong influence on efficiency witnessed here is in good agreement with published work [43]. The amount of recirculated fuel decreases with $U_{f}$ as less fuel needs to be recirculated to meet the specified STCR due to the increased $\mathrm{H}_{2} \mathrm{O}$ content in the depleted fuel. As a result of less high temperature depleted fuel being recirculated the pre-reformer/anode temperature drops and thus the $\mathrm{CH}_{4}$ conversion fraction is lowered (the effect of temperature on $\mathrm{CH}_{4}$ conversion is discussed in section 4.3). The cathode and stack exhaust temperatures are dependent on the combustion temperature, which is determined by the amount of fuel available to the combustion plenum. At low $U_{f}$ more of the fuel is available for combustion therefore the temperatures are high and as $U_{f}$ increases (more fuel energy converted to electricity as opposed to heat) the temperatures decrease. Considering the findings above it is recommended to operate the SOFC stack at high fuel utilisation but below the level where the concentration loss increases to a very high degree (typical $U_{f}=0.85$ ).
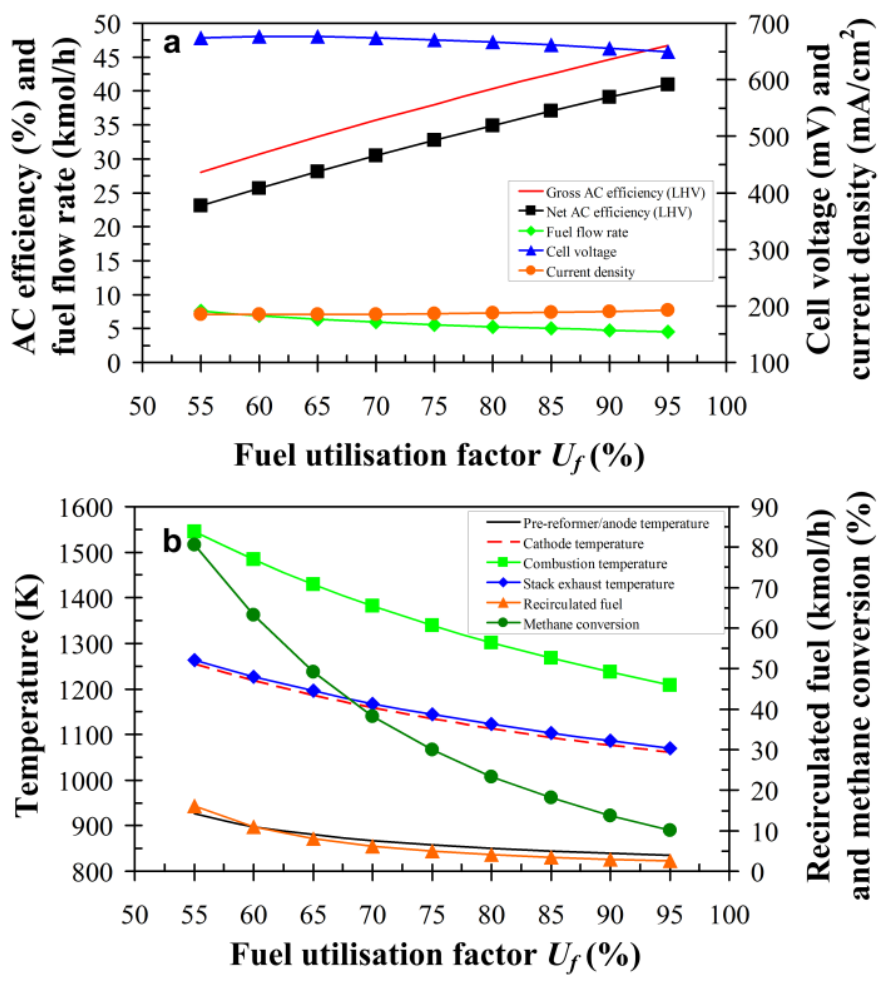

Fig. 4. Effect of fuel utilisation factor on (a) voltage, efficiency, fuel flow rate and current density and (b) prereformer/anode temperature, cathode temperature, combustion temperature, stack exhaust temperature, recirculated fuel and methane conversion. 


\subsection{Sensitivity analysis: current density}

Fig. 5 shows that varying $j$ has significant influence on the system. Increasing $j$ from 50 to $420 \mathrm{~mA} / \mathrm{cm}^{2}$ decreases both efficiency and voltage but increases power. Voltage is lowered significantly as a result of higher voltage losses. Efficiency decreases substantially (32 percentage points over the $j$ range) due to higher parasitic power (fuel and air compressors) and energy input as a result of increased fuel and air flow rate. Stack power increases and reaches a peak at $330 \mathrm{~mA} / \mathrm{cm}^{2}$ and then decreases. Fuel cells are usually operated to the left of this peak power. It is desirable with regard to operating costs, to operate the SOFC stack at a high voltage and efficiency; however it is also desirable with regard to capital costs, to operate the SOFC stack at high power (less SOFCs needed). Therefore there must be a trade-off between voltage, efficiency and power. These trends and the need for a compromise between efficiency and capital costs match results reported elsewhere [43]. A typical operating $j$ range is $180-200 \mathrm{~mA} / \mathrm{cm}^{2}$, corresponding to a cell voltage of $672.9-647.5 \mathrm{mV}, \eta_{\text {el,gross }}=43.2-41.6 \%, \eta_{\text {el, net }}=37.8-$ $36.1 \%$ and $P_{e l, A C}=107-114.5 \mathrm{~kW}$.

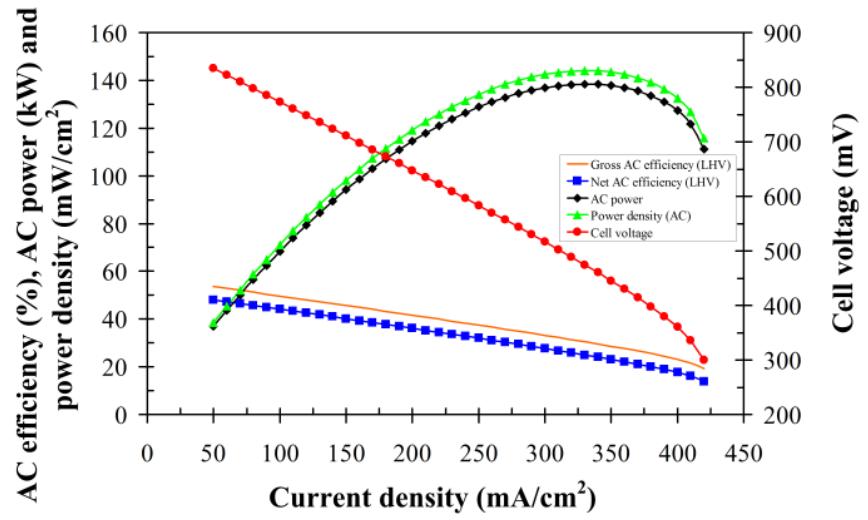

Fig. 5. Effect of current density on voltage, efficiency and power.

\subsection{Sensitivity analysis: steam to carbon ratio}

The effects of varying STCR are displayed in Figs. 6 and 7. From Fig. 6 it can be seen that STCR has a substantial impact on the pre-reformer, the inlet temperature increases from 681 to $1002 \mathrm{~K}$ over the STCR range due to the recirculation of more high temperature depleted fuel. As a result the anode temperature rises (831 to $906 \mathrm{~K}$ ) 
and causes greater $\mathrm{CH}_{4}$ conversion (0 to $92.2 \%$ ). The high temperature and greater amount of steam available promotes the steam reforming of $\mathrm{CH}_{4}$ via Eq. (1). This reaction is endothermic meaning the forward reaction is favoured as temperature increases. Increasing $S T C R$ has a negative impact on voltage and efficiency and increases $j$, this is due to the change in anode temperature and gaseous component partial pressures, which decreases the Nernst voltage and increases the voltage losses. It is therefore desirable to operate the stack at low STCR. Once again these results agree well with the literature [29, 43]. Fig. 7 displays how STCR affects the pre-reformer outlet or anode inlet gas composition. As expected increasing STCR causes the mole fraction of $\mathrm{H}_{2} \mathrm{O}$ and $\mathrm{CO}_{2}$ to rise, this lowers the mole fraction of $\mathrm{H}_{2}$ and $\mathrm{CO}$ negatively affecting stack performance. The $\mathrm{CH}_{4}$ content decreases over the STCR range due to the high temperature and greater amount of steam available for reforming. Considering the findings above it is recommended to operate the SOFC stack at low STCR but high enough to ensure no carbon formation problems.
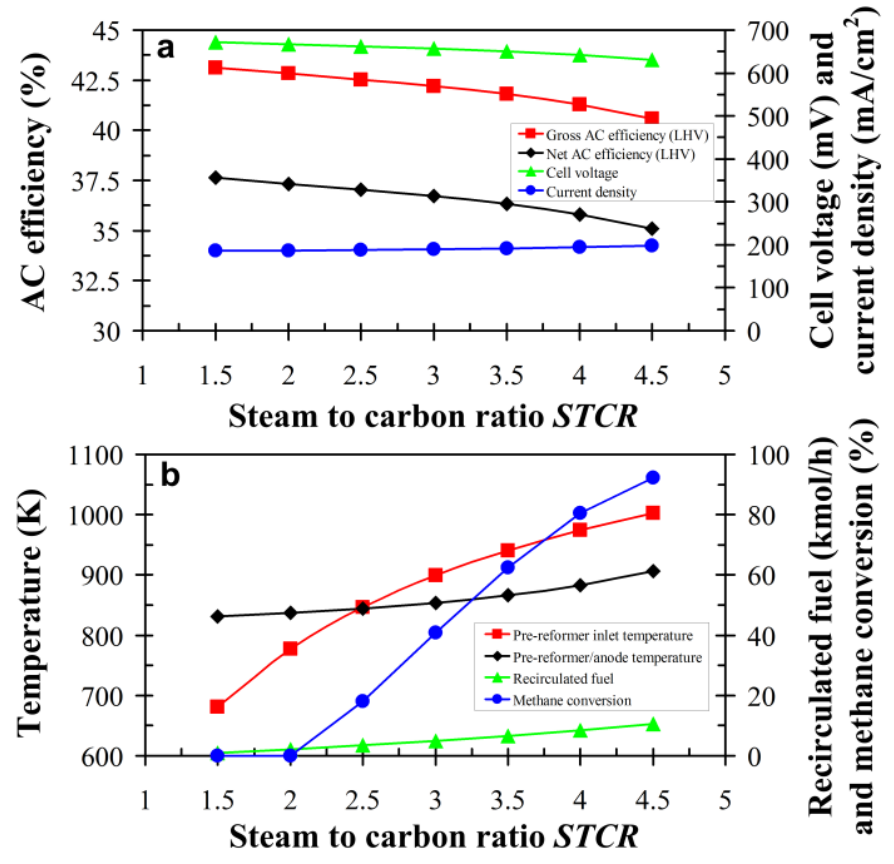

Fig. 6. Effect of steam to carbon ratio on (a) voltage, efficiency and current density and (b) pre-reformer inlet temperature, pre-reformer/anode temperature, recirculated fuel and methane conversion. 


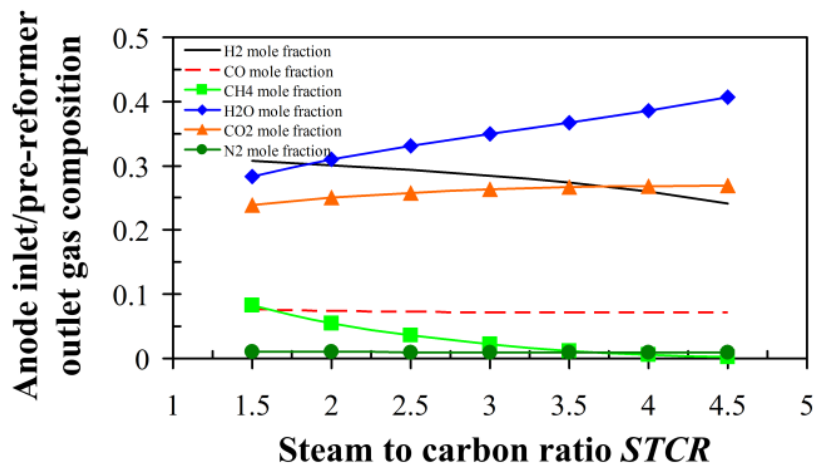

Fig. 7. Effect of steam to carbon ratio on anode inlet/pre-reformer outlet gas composition.

\subsection{Performance comparison with Güssing CHP plant}

Table 7 compares the performance of the SOFC system (realistic design operating conditions) with the performance of the Güssing CHP plant. It is difficult to compare the two systems as they are operating at very different power levels (difference in $P_{e l, A C}$ ). The plant gross electrical efficiency given in Table 7 was determined as follows. For the Güssing CHP plant the electrical power $\left(P_{e l, A C}\right)$ was divided by the biomass input, $8000 \mathrm{~kW}$ [27] giving the gross electrical efficiency. For the SOFC system a simplification needed to be made as the overall plant has not yet been modelled. The work described in this article is part of on-going research which aims to simulate biomass gasification integrated with SOFC stacks and associated balance of plant components (cleaning and heat recovery). In order to compare the two systems it has been assumed that the DFB gasifier achieves a cold gas efficiency (CGE) of 78.4\% [44]. This CGE multiplied by the standalone SOFC stack electrical efficiency $\left(\eta_{\text {el,gross }}=\right.$ $42.53 \%$ ) gives a good indication of the plant gross electrical efficiency (Table 7). From Table 7 it is noted that if the gas engine were replaced with a SOFC the plant electrical efficiency would increase by approximately 8 percentage points, which demonstrates the attractiveness of the SOFC technology. The two systems are also compared on a thermal basis. The useful heat $(\dot{Q})$ for the SOFC system listed in Table 7 was determined assuming that the stream 11 (Fig. 3) preheats the cathode air from $34.3^{\circ} \mathrm{C}$ to $819.7^{\circ} \mathrm{C}$ resulting in a stack exhaust (stream 12) temperature of $321.4{ }^{\circ} \mathrm{C}$. The plant gross CHP efficiency was then calculated using:

$\eta_{C H P, \text { gross }}=\frac{P_{e l, A C}+\dot{Q}}{\dot{m}_{\text {biomass }} \cdot L H V_{\text {biomass }}}$ 
Equation 30 was used to determine the gross CHP efficiency for the Güssing plant (80.75\%), which resulted in a CHP efficiency very close to reported efficiencies for the plant (81.3\%) [45-47]. The reader should note that for the SOFC system, heat that could be recovered through syn-gas cooling and from the DFB gasifier combustion zone flue gas has not been considered as the overall plant has not been modelled. This explains the lower CHP efficiency for the SOFC system when compared to the Güssing system. It is expected that inclusion of this additional heat would raise the SOFC system CHP efficiency to a comparable level. Finally, the systems are compared on a powerto-heat ratio basis, revealing a low ratio for the Güssing type system indicating a higher heat than electricity output and a much higher ratio for the SOFC system indicating that the quantity of electricity produced is closer to the level of useful heat. Depending on the requirements of the consumer the SOFC fuel utilisation factor could be adjusted in order to vary the power-to-heat ratio.

\section{Table 7}

Performance comparison between SOFC system and Güssing CHP plant.

\begin{tabular}{lcccccc}
\hline System & $\begin{array}{l}\text { Biomass } \\
\text { input } \\
(\mathrm{kW})\end{array}$ & $\begin{array}{l}P_{\text {el,AC }} \\
(\mathrm{kW})\end{array}$ & $\begin{array}{l}\text { Plant gross elec- } \\
\text { trical efficiency } \\
(\%)\end{array}$ & $\begin{array}{l}\dot{Q} \\
(\mathrm{~kW})\end{array}$ & $\begin{array}{l}\text { Plant gross CHP } \\
\text { efficiency } \\
(\%)\end{array}$ & $\begin{array}{l}\text { Power-to- } \\
\text { heat ratio } \\
\text { (gross) }\end{array}$ \\
\hline SOFC & 331.19 & 110.4 & 33.34 & 135.09 & 74.12 & 0.82 \\
Güssing CHP & $8000^{\mathrm{a}}$ & $1960^{\mathrm{a}}$ & 24.5 & $4500^{\mathrm{a}}$ & 80.75 & 0.44 \\
\hline
\end{tabular}

${ }^{\mathrm{a}}$ Data from Pröll and Hofbauer [27].

\section{Conclusions}

A computer model of the SPGI $100 \mathrm{~kW}$ AC CHP tubular SOFC stack was developed using Aspen Plus. The objective of the work, which was to develop a model of a biomass-SOFC system capable of predicting performance under diverse operating conditions, was achieved. The model uses existing Aspen Plus unit operation blocks with minimum requirements for linking of a subroutine thus reducing complexity and ensuring short computational times. It was validated against published data for the SPGI $100 \mathrm{~kW}$ CHP SOFC stack operating on natural gas. Sensitivity analyses were carried out in order to give insight into the influence of the main variables on the system. The effects of varying fuel utilisation factor, current density and steam to carbon ratio on SOFC stack performance were investigated for the stack operating on Güssing biomass syn-gas, the results of which revealed the following: 
- The efficiency gain with increasing $U_{f}$ outweighs the reduction in voltage; therefore the stack should be operated at high $U_{f}$.

- There must be a trade-off between voltage, efficiency and power with respect to $j$. For $j=180-200 \mathrm{~mA} / \mathrm{cm}^{2}$, cell voltage $=672.9-647.5 \mathrm{mV}, \eta_{e l, g r o s s}=43.2-41.6 \%, \eta_{e l, \text { net }}=37.8-36.1 \%$ and $P_{e l, A C}=107-114.5 \mathrm{~kW}$.

- The stack should be operated at a low STCR but high enough to ensure no carbon formation problems.

- Stack operation on Güssing biomass syn-gas compared to natural gas at $j=182.86 \mathrm{~mA} / \mathrm{cm}^{2}$ : voltage decreased by $14 \mathrm{mV}$ to $669 \mathrm{mV}$, DC power dropped $2.43 \mathrm{~kW}$ to $117.57 \mathrm{~kW}$ and the gross and net $\mathrm{AC}$ efficiency reduced $8.28 \%$ and $11.63 \%$ to $43 \%$ and $37.52 \%$ respectively.

- The realistic design operating conditions with regard to stack performance were identified: $S T C R=2.5, U_{f}=$ $0.85, \mathrm{DC}$ power $=120 \mathrm{~kW}, j=188.7 \mathrm{~mA} / \mathrm{cm}^{2}, V=662 \mathrm{mV}, \eta_{e l, \text { gross }}=42.53 \%$ and $\eta_{e l, n e t}=37.04 \%$.

The reduction in efficiency seen for syn-gas operation is attributed to increased fuel and air flow rates due to the lower quality of the fuel gas. Even with this performance decrease the efficiency achieved is much higher than traditional biomass systems. The performance comparison presented in section 4.4 revealed that if the gas engine operating at the Güssing CHP plant were replaced with a SOFC the plant electrical efficiency would increase by approximately 8 percentage points, which demonstrates the attractiveness of the SOFC technology. 


\section{References}

[1] Seitarides T, Athanasiou C, Zabaniotou A. Modular biomass gasification-based solid oxide fuel cells (SOFC) for sustainable development. Renewable and Sustainable Energy Reviews 2008;12:1251-1276.

[2] Cordiner S, Feola M, Mulone V, Romanelli F. Analysis of a SOFC energy generation system fuelled with biomass reformate. Applied Thermal Engineering 2007;27:738-747.

[3] Fryda L, Panopoulos KD, Kakaras E. Integrated CHP with autothermal biomass gasification and SOFCMGT. Energy Conversion and Management 2008;49:281-290.

[4] Panopoulos KD, Fryda LE, Karl J, Poulou S, Kakaras E. High temperature solid oxide fuel cell integrated with novel allothermal biomass gasification: Part I: Modelling and feasibility study. Journal of Power Sources 2006;159:570-585

[5] Pröll T, Rauch R, Aichernig C, Hofbauer H. Coupling of biomass steam gasification and an SOFC-gas turbine hybrid system for highly efficient electricity generation. ASME Turbo Expo: Power for Land, Sea, and Air, Vienna, Austria, 2004

[6] Sucipta M, Kimijima S, Song TW, Suzuki K. Biomass solid oxide fuel cell-microgas turbine hybrid system: Effect of fuel composition. Journal of Fuel Cell Science and Technology 2008;5:041006-1-8.

[7] Suwanwarangkul R, Croiset E, Pritzker MD, Fowler MW, Douglas PL, Entchev E. Modelling of a cathodesupported tubular solid oxide fuel cell operating with biomass-derived synthesis gas. Journal of Power Sources 2007; 166:386-399.

[8] Fryda L, Panopoulos KD, Karl J, Kakaras E. Exergetic analysis of solid oxide fuel cell and biomass gasification integration with heat pipes. Energy 2008;33:292-299.

[9] Karellas S, Karl J, Kakaras E. An innovative biomass gasification process and its coupling with microturbine and fuel cell systems. Energy 2008;33:284-291.

[10] Schuster G, Löffler G, Weigl K, Hofbauer H. Biomass steam gasification - an extensive parametric modeling study. Bioresource Technology 2001;77:71-79.

[11] Doherty W, Reynolds A, Kennedy D. The effect of air preheating in a biomass CFB gasifier using ASPEN Plus simulation. Biomass and Bioenergy 2009;33:1158-1167.

[12] Doherty W, Reynolds A, Kennedy D. Simulation of a Circulating Fluidised Bed Biomass Gasifier Using ASPEN Plus - A Performance Analysis. In: Ziebik A, Kolenda Z, Stanek W, editors. 21st International 
Conference on Efficiency, Cost, Optimization, Simulation and Environmental Impact of Energy Systems, Krakow, Poland, vol. 3. 2008. p. 1241-1248.

[13] Santin M, Traverso A, Magistri L, Massardo A. Thermoeconomic analysis of SOFC-GT hybrid systems fed by liquid fuels. Energy 2010;35:1077-1083.

[14] Bessette NF, Wepfer WJ, Winnick J. A mathematical model of a solid oxide fuel cell. Journal of the Electrochemical Society 1995;142:3792-3800.

[15] Bharadwaj A, Archer DH, Rubin ES. Modeling the performance of a tubular solid oxide fuel cell. Journal of Fuel Cell Science and Technology 2005;2:38-44.

[16] Campanari S. Thermodynamic model and parametric analysis of a tubular SOFC module. Journal of Power Sources 2001;92:26-34.

[17] Cali M, Santarelli MGL, Leone P. Design of experiments for fitting regression models on the tubular SOFC : Screening test, response surface analysis and optimization. International Journal of Hydrogen Energy $2007 ; 32: 343-358$.

[18] Hirano A, Suzuki M, Ippommatsu M. Evaluation of a New Solid Oxide Fuel Cell System by Non-isothermal Modeling. Journal of the Electrochemical Society 1992;139:2744-2751.

[19] Campanari S, Iora P. Definition and sensitivity analysis of a finite volume SOFC model for a tubular cell geometry. Journal of Power Sources 2004;132:113-126.

[20] Franzoni A, Magistri L, Traverso A, Massardo AF. Thermoeconomic analysis of pressurized hybrid SOFC systems with CO2 separation. Energy 2008;33:311-320.

[21] Kakaç S, Pramuanjaroenkij A, Zhou XY. A review of numerical modeling of solid oxide fuel cells. International Journal of Hydrogen Energy 2007;32:761-786.

[22] Zhang W, Croiset E, Douglas PL, Fowler MW, Entchev E. Simulation of a tubular solid oxide fuel cell stack using AspenPlusTM unit operation models. Energy Conversion and Management 2005;46:181-196.

[23] Song TW, Sohn JL, Kim JH, Kim TS, Ro ST, Suzuki K. Performance analysis of a tubular solid oxide fuel cell/micro gas turbine hybrid power system based on a quasi-two dimensional model. Journal of Power Sources 2005;142:30-42.

[24] Achenbach E. Three-dimensional and time-dependent simulation of a planar solid oxide fuel cell stack. Journal of Power Sources 1994;49:333-348. 
[25] Chan SH, Khor KA, Xia ZT. A complete polarization model of a solid oxide fuel cell and its sensitivity to the change of cell component thickness. Journal of Power Sources 2001;93:130-140.

[26] Gariglio M, De Benedictis F, Santarelli M, Calì M, Orsello G. Experimental activity on two tubular solid oxide fuel cell cogeneration plants in a real industrial environment. International Journal of Hydrogen Energy 2009;34:4661-4668.

[27] Pröll T, Hofbauer H. Development and application of a simulation tool for biomass gasification based processes. International Journal of Chemical Reactor Engineering 2008;6:A89.

[28] Meyer L, Tsatsaronis G, Buchgeister J, Schebek L. Exergoenvironmental analysis for evaluation of the environmental impact of energy conversion systems. Energy 2009;34:75-89.

[29] Cocco D, Tola V. Externally reformed solid oxide fuel cell-micro-gas turbine (SOFC-MGT) hybrid systems fueled by methanol and di-methyl-ether (DME). Energy 2009;34:2124-2130.

[30] Lunghi P, Burzacca R. Energy recovery from industrial waste of a confectionery plant by means of BIGFC plant. Energy 2004;29:2601-2617.

[31] Costamagna P, Magistri L, Massardo AF. Design and part-load performance of a hybrid system based on a solid oxide fuel cell reactor and a micro gas turbine. Journal of Power Sources 2001;96:352-368.

[32] Hofmann P, Panopoulos KD, Fryda LE, Kakaras E. Comparison between two methane reforming models applied to a quasi-two-dimensional planar solid oxide fuel cell model. Energy 2009;34:2151-2157.

[33] Komatsu Y, Kimijima S, Szmyd JS. Performance analysis for the part-load operation of a solid oxide fuel cell-micro gas turbine hybrid system. Energy 2010;35:982-988.

[34] Singhal SC. Advances in solid oxide fuel cell technology. Solid State Ionics 2000;135:305-313.

[35] Williams MC, Strakey JP, Singhal SC. U.S. distributed generation fuel cell program. Journal of Power Sources 2004;131:79-85.

[36] Calise F, Dentice d' Accadia M, Vanoli L, von Spakovsky MR. Full load synthesis/design optimization of a hybrid SOFC-GT power plant. Energy 2007;32:446-458.

[37] Calise F, d'Accadia MD, Palombo A, Vanoli L. One-dimensional model of a tubular solid oxide fuel cell. Journal of Fuel Cell Science and Technology 2008;5:021014-1-15.

[38] Arpino F, Massarotti N. Numerical simulation of mass and energy transport phenomena in solid oxide fuel cells. Energy 2009;34:2033-2041. 
[39] Todd B, Young JB. Thermodynamic and transport properties of gases for use in solid oxide fuel cell modelling. Journal of Power Sources 2002;110:186-200.

[40] Fuller EN, Schettler PD, Giddings JC. A new method for prediction of binary gas-phase diffusion coefficients. Industrial and Engineering Chemistry 1966;58:19-27.

[41] EG\&G Technical Services. Fuel Cell Handbook. US Department of Energy, 2004.

[42] Verda V, Calí Quaglia M. Solid oxide fuel cell systems for distributed power generation and cogeneration. International Journal of Hydrogen Energy 2008;33:2087-2096.

[43] Calise F, Dentice d'Accadia M, Palombo A, Vanoli L. Simulation and exergy analysis of a hybrid Solid Oxide Fuel Cell (SOFC)-Gas Turbine System. Energy 2006;31:3278-3299.

[44] Gassner M, Maréchal F. Thermodynamic comparison of the FICFB and Viking gasification concepts. Energy 2009;34:1744-1753.

[45] Hofbauer H, Rauch R, Bosch K, Koch R, Aichernig C. Biomass CHP Plant Güssing - A Success Story. Expert Meeting on Pyrolysis and Gasification of Biomass and Waste, Strasbourg, France, 2002.

[46] Rauch R, Hofbauer H, Bosch K, Siefert I, Aichernig C, Tremmel H et al. Steam gasification of biomass at CHP plant in Guessing - status of the demonstration plant. 2nd World Conference and Technology Exhibition on Biomass for Energy, Industry and Climate Protection, Rome, Italy, 2004.

[47] Bolhar-Nordenkampf M, Hofbauer H. Gasification demonstration plants in Austria. IV International Slovak Biomass Forum, Bratislava, 2004. 